\title{
Tolerance of High Inorganic Mercury of Perna viridis: Laboratory Studies of Its Accumulation, Depuration and Distribution
}

\author{
${ }^{* 1}$ YAP, C K; ${ }^{1}$ ISMAIL A; ${ }^{1}$ TAN, S G; ${ }^{1}$ OMAR, H $;{ }^{2}$ KOYAMA, J \\ ${ }^{I}$ Department of Biology, Faculty of Science, Universiti Putra Malaysia, 43400 UPM Serdang, Selangor, Malaysia. \\ Tel: 603-89466616, Fax: 603-86567454 \\ ${ }^{2}$ Education and Research Center for Marine Resources and Environment, Faculty of Fisheries, Kagoshima University, 4-50-29, \\ Shimoarata, Kagoshima 890-0056, Japan.
}

\begin{abstract}
The tolerance of Perna viridis to a high inorganic mercury (Hg) exposure was determined based on its accumulation, depuration and distribution. The $\mathrm{Hg}$ accumulation of the mussel was conducted for a 4-day semi-static exposure at a 'very' high $\mathrm{Hg}$ concentration $(100 \mu \mathrm{g} / \mathrm{L})$. None of the mussels died after the experimental period, indicating that the elevated level of inorganic $\mathrm{Hg}$ exposure was not toxic to $P$. viridis. Following the 4-day exposure, the $\mathrm{Hg}$ concentrations were higher in the gill and byssus than in the mantle, foot, gonad and muscle (with bioconcentration factor values being between 13 and 625). The $\mathrm{Hg}$ distribution among the different soft tissues after 11 days of depuration was almost similar with that after $\mathrm{Hg}$ exposure. The high $\mathrm{Hg}$ levels found in the byssus and different soft tissues after the depuration indicated that $\mathrm{Hg}$ accumulated in the different ST was tightly bound to metallothionein and it was not easily mobilized. The $\mathrm{Hg}$ distribution in the byssus and in the different soft tissues could be due to their differing capacities for $\mathrm{Hg}$ accumulation and depuration. Since the soft tissues of $P$. viridis can accumulate inorganic $\mathrm{Hg}$ in high concentrations after exposing to a 'very' high level of inorganic $\mathrm{Hg}$, it has a high bioaccumulative capability and a high tolerance to inorganic $\mathrm{Hg}$. The mussel byssus was found to have the highest depuration rate coefficient, indicating that it could act as one of the excretion routes for $\mathrm{Hg}$ and it can be proposed as a sensitive biomonitoring material for $\mathrm{Hg}$. The fecal materials released by the mussel had elevated levels of $\mathrm{Hg}$, indicating that the mussels acted as a $\mathrm{Hg}$ retention mechanism in the coastal ecosystem. @JASEM
\end{abstract}

Mercury $(\mathrm{Hg})$ is one of the heavy metals in the marine ecosystem that cause most concern if it is present at an elevated level as it could have hazardous impacts due to its toxicity. The most notorious example of $\mathrm{Hg}$ toxicity was the Minamata outbreak in Japan during which several people died or became terminally ill after consuming fish and shellfish containing relatively high concentrations of methyl-Hg (Kurland, 1960). Later, more evidences for the hazardous risks caused by consuming food containing high $\mathrm{Hg}$ levels were also reported from countries like Iraq (Mance, 1987). Evidence of this concern to public health was shown by the number of papers reporting on $\mathrm{Hg}$ contamination in the biota related to human beings (Leah et al., 1982; De Gregori et al., 1984; Schuhmacher et al., 1994; Moraes et al., 1997; Alonso et al., 2000; Zhou and Wong, 2000).

Of the total $\mathrm{Hg}$, methyl-Hg is the most toxic form of $\mathrm{Hg}$ from the human health point of view. Although we did not measure the level of methyl$\mathrm{Hg}$ in the mussels, we assumed that an elevated level of elemental $\mathrm{Hg}$ reflected also a high level of methyl-Hg. May et al. (May et al., 1987) reported that about $20-56 \%$ of total $\mathrm{Hg}$ consisted of methyl$\mathrm{Hg}$ in marine mussels.

The green-lipped mussel Perna viridis, has been a suitable candidate for biomonitoring studies in the
Asia-Pacific coastal waters (Tanabe, 2000). Based on the international 'Mussel Watch' approach developed a few decades ago (Goldberg, 1975), Ismail et al. (2000) proposed the use of $P$. viridis as a potential biomonitoring agent for heavy metals in the west coast of Peninsular Malaysia since it fulfills the important criteria to be a good biomonitor namely its wide geographical distribution in the west coast of Peninsular Malaysia, sedentary lifestyle, reasonable abundance and availability throughout the year, easy identification and sampling and importance both ecologically and economically. The marine mussels are also bioaccumulative and they have correlative properties with the average pollutants of the environment, tolerance to natural environmental fluctuations and pollution (Goldberg, 1975; Goldberg et al., 1978; Phillips, 1985, 1991, Phillips and Segar, 1986; Phillips and Rainbow, 1993; Wong et al., 2000). In addition, mussels are able to integrate metal concentration in water over time (Bryan, 1984; Phillips, 1980). However, in $P$. viridis, the bioaccumulative capability based on laboratory conditions has not been reported before. Metal accumulation in mussels can be of importance from the public health point of view and can be exploited in the assessment of environmental quality (Davies and Pirie, 1978). However, the public health standpoint is only of much concern if the mussels could 
accumulate an extremely high level of metal. Perhaps, natural field samples could not be able to provide this information on the very high level of metal if they are sampled from an unpolluted area. Therefore, exposing the mussels to an elevated level of metal under laboratory condition could provide information on the bioaccumulative capability for the metal and its tolerance to the high metal level. Questions of 'Can $P$. viridis survive at the $100 \mu \mathrm{g} / \mathrm{L} \mathrm{Hg}$ exposure?' and 'What is the bioaccumulative capability (based on bioconcentration factor) of $P$. viridis at the high level of inorganic $\mathrm{Hg}$ exposure ?' are equally interesting.

In this study, we looked into the metal accumulation by $P$. viridis exposed to a 'very' high level of inorganic $\mathrm{Hg}$ from the dissolved solution phase of seawater since the bioavailability of inorganic $\mathrm{Hg}$ had been demonstrated to be mainly from the dissolved phase (Davies and Pirie, 1978; Eganhouse and Young, 1978). Sakamoto et al. (1999) reported that inorganic Hg in the seawater of the Straits of Malacca ranged from 0.8 to 41 $\mathrm{ng} / \mathrm{L}$. We used 100, $000 \mathrm{ng} / \mathrm{L}(100 \mu \mathrm{g} / \mathrm{L})$ inorganic $\mathrm{Hg}$ for the exposure study, a concentration considered as 'very' high. The mussel tolerance of such a very high $\mathrm{Hg}$ level had not been studied before. Besides, the internal distribution of the $\mathrm{Hg}$ resulting from its accumulation from the dissolved inorganic $\mathrm{Hg}$ in the seawater and its depuration were also interesting to study. Therefore, the objective of this study was to determine the tolerance and the accumulation, depuration and distribution of $100 \mu \mathrm{g} / \mathrm{L}$ inorganic $\mathrm{Hg}$ exposure under laboratory conditions.

\section{MATERIALS AND METHODS}

Individuals of $P$. viridis were collected from unpolluted water at Sebatu $\left(02^{\circ} 07^{\prime} \mathrm{N}, 102^{\circ} 21^{\prime} \mathrm{E}\right)$ off the west coast of Peninsular Malaysia. After removing the encrusting organisms such as barnacles and bryzoa and cleaning the shell surfaces, all the mussels were transported to the laboratory at the Institute of Bioscience's hatchery, Universiti Putra Malaysia. During the 3-day acclimatization, seawater was changed and spawning was observed in the mussels. The mussels were fed with monocultured alga Isochrysis galbana. Mussels of similar size (4-5 $\mathrm{cm}$ ) and had their spawns released were chosen for this study because the spawned mussels had the least effects of physiological conditions on metal accumulation (Broman et al., 1991). The seawater used was filtered through a plankton net with 200 $\mu \mathrm{m}$ meshes to remove suspended particles.
The accumulation and depuration studies were conducted in experimental aquaria. Fifteen mussels were exposed in each glass aquarium. The experimental aquarium for the accumulation and depuration study of $\mathrm{Hg}$ and one control aquarium were run through during the experimental period. Before the start of $\mathrm{Hg}$ exposure, three mussels were collected for background $\mathrm{Hg}$ analysis. At day 0, 20 litre of filtered seawater were placed into the aquaria and a standard solution of mercuric nitrate (Wako Pure Chem., Tokyo, Japan) was mixed into the aquarium to provide a dissolved $\mathrm{Hg}$ concentration of $100 \mu \mathrm{g} / \mathrm{L}$. After two days of $\mathrm{Hg}$ exposure, three mussels were collected and the test seawater was replaced with newly filtered 20-litre seawater. Again, the test seawater was adjusted to $100 \mu \mathrm{g} / \mathrm{L} \mathrm{Hg}$, together with a monocultured alga Isochrysis galbana as the food source. The measured $\mathrm{Hg}$ concentrations in the seawater after adding the $\mathrm{Hg}$ standard were close to the nominal values.

At day 4, three mussels were sampled from each aquarium and the seawater was changed without $\mathrm{Hg}$ addition. Mussel samplings were conducted after 2 (day 6), 7 (day 11) and 11 (day 15) days of $\mathrm{Hg}$ depuration. During the depuration period, the seawater was changed and the mussels were fed with I. galbana at the same period of sampling. The test solution (20 litre) in the semi-static experiment was constantly aerated and was held at room temperature $\left(26-29^{\circ} \mathrm{C}\right)$, salinity at $18-20 \mathrm{ppt}$, dissolved oxygen at $6.9-7.4 \mathrm{mg} / \mathrm{L}(80-90 \%), \mathrm{pH}$ 7.55-7.72, during the experimental period.

Upon termination of the experiment, the soft tissues of $P$. viridis were shucked from the shell. They were dissected into gill, mantle, byssus, muscle, gonad and foot. They were placed onto filter paper (Whatman No. 1) to drain away excess water content.

To determine the total $\mathrm{Hg}$ of the mussel soft tissues and seawater, the heat vaporization method of analysis was conducted on the fresh samples by using a Hg Analyser Model MA-1S. The data were presented as ng/g wet weight basis. The analytical method (USEPA method 7473) used two different types of additives (activated alumina and calcium hydroxide) to minimize the effects of the measurement interruptive materials of the sample. The additive application followed the procedure described in the instruction manual for the $\mathrm{Hg}$ /MA-1S (Nippon Instrument Corp). The accuracy of the data was checked by performing a recovery test by using a quality control sample made from standard mercuric nitrate solution (Wako Pure 
Chem., Japan) before and after each day of measurement. The recovery for the $\mathrm{Hg}$ was between $90-100 \%$.

Data Analysis: The bioconcentration factor (BCF) was determined to provide general information on how enriched $\mathrm{Hg}$ in the byssus and different soft tissues of $P$. viridis were, with respect to $\mathrm{Hg}$ concentrations in their environmental seawater (Reinfelder et al., 1998). To obtain this information, a 4-day BCF value was calculated in byssus and each of the soft tissues as shown below:-

$$
\mathrm{BCF}=\frac{\mathrm{Ce}-\mathrm{Ci}}{\mathrm{Cs}}
$$

$\mathrm{Ce}=$ the metal concentration in the exposed organ at the end of metal exposure (ng/g wet weight)

$\mathrm{Ci}=$ the metal concentration in the control group at the end of metal exposure (ng/g wet weight)

$\mathrm{Cs}=$ the experimental metal concentration $(\mu \mathrm{g} / \mathrm{L})$ in the aquarium test seawater.

The Student-Newman-Keuls (SNK) test (Day and Quinn, 1989) was used to elucidate where differences occurred. All comparisons were made at least at the $95 \%(P<0.05)$ level of significance. To obtain the depuration rate coefficients, the depuration data of $\mathrm{Hg}$ were fitted to the following power relationship:-

$\mathrm{Y}=\mathrm{aX}$

where $Y=$ metal concentration in the mussels at time $\mathrm{X}$;

$\mathrm{a}=$ metal concentration in the mussels at the start of the depuration experiment;

$\mathrm{b}=$ depuration rate coefficient $\left(\right.$ day $\left.^{-1}\right)$;

$\mathrm{X}=$ time of depuration (day).

This model was used because it gave relatively high $R$-values for the byssus and all the different soft tissues. Regressions of the depuration data were based on $\log _{10}(\mathrm{ng} / \mathrm{g})$ transformed of $\mathrm{Hg}$ depuration on the mussels and the untransformed period (Day +4$)$ of the depuration study.

\section{RESULTS AND DISCUSSION}

Figure 1 shows that the levels of accumulation of $\mathrm{Hg}$ in the different soft tissues of $P$. viridis were highly dependent on the periods of $\mathrm{Hg}$ exposure and were highly sensitive to the dissolved inorganic $\mathrm{Hg}$ in the test seawater since there were decreased levels of $\mathrm{Hg}$ in the soft tissues of $P$. viridis during the depuration period. None of the experimental mussels died after the 4-day of exposure. After 4-day of exposure, the $\mathrm{Hg}$ (ng/g wet weight) were accumulated in the following order: gill (62500) > byssus (30100) $>$ mantle (3000) $>$ foot $(1980)>\operatorname{gonad}(1960)>$ muscle (1350). Similarly, the BCF values (Table 1) after the 4 days of $\mathrm{Hg}$ exposure also followed the same order in that the gill recorded the highest BCF value (625) and the lowest value was found in muscle (13). After 11 days (day 15) of depuration, the $\mathrm{Hg}$ levels (ng/g wet weight) in the different soft tissues were in the following order: gill (4600) > byssus $(4140)>\operatorname{mantle}(1100)>\operatorname{gonad}(880)>$ foot $(800)>$ muscle (400). At the end of $\mathrm{Hg}$ depuration, all the soft tissues were able to retain 22 to 185 times higher $\mathrm{Hg}$ levels when compared to the background levels before the $\mathrm{Hg}$ exposure.

Figure 2 shows that the byssus had the highest depuration rate coefficient $(b=-0.196)$, followed by gill $(b=-0.189)$, muscle $(b=-0.134)$, mantle $(b=-$ $0.095)$, gonad $(b=-0.092)$ and foot $(b=-0.086)$. Table 2 shows the $\mathrm{Hg}$ levels in fecal materials of $P$. viridis during the accumulation and depuration periods. The results indicated that fecal materials produced by $P$. viridis contained more than $100,000 \mathrm{ng} / \mathrm{g} \mathrm{Hg}$ (higher than the detection limit) during the accumulation periods. Similarly, fecal materials recorded elevated $\mathrm{Hg}$ levels ( $>100,000$ $\mathrm{ng} / \mathrm{g}$ ) during the depuration period. In the control group, the higher levels of $\mathrm{Hg}(121-365 \mathrm{ng} / \mathrm{g})$ in the fecal materials during the experimental period than in day $0(48 \mathrm{ng} / \mathrm{g})$ might be due to the algae fed to the mussels once in every two days containing some contaminated $\mathrm{Hg}$. However, these levels were significantly $(P<0.001)$ lower than those in the exposed mussels that were higher than the detection limit set by the Hg model MA-1S.

These results showed the ability of $P$. viridis to accumulate $\mathrm{Hg}$ at elevated levels in the byssus and in the different soft tissues without signs of mortality when the mussels were exposed to elevated levels of inorganic $\mathrm{Hg}(100 \mu \mathrm{g} / \mathrm{L})$. This indicated that $P$. viridis was tolerant to inorganic $\mathrm{Hg}$ contamination and the high $\mathrm{Hg}$ level was not toxic to the mussel.

The distribution of $\mathrm{Hg}$ in the soft tissues of $P$. viridis indicated that different soft tissues were responding to $\mathrm{Hg}$ by different physiological functions and that metallothionein might play a role in regulating the $\mathrm{Hg}$ excretion as well as storage (Roesijadi, 1980). The high retention of $\mathrm{Hg}$ in the different soft tissues even after 11 days of depuration also indicated that the $\mathrm{Hg}$ was bound to metallothioneins in a fixed position (Roesijadi, 1980). Such a mechanism has been shown to exist through the induction and synthesis of metallothionein which is characteristically high in cysteine residues and binds rapidly and strongly with Hg (Cherian and Goyer, 1978; Roesijadi, 
1980). The high affinity for $\mathrm{Hg}$ may well be responsible for the greater $\mathrm{Hg}$ accumulation rate observed in the gill and byssus when compared to the other soft tissues that were examined. The lower $\mathrm{Hg}$ levels in the foot, muscle, mantle and gonad could be due to the metal-binding proteins
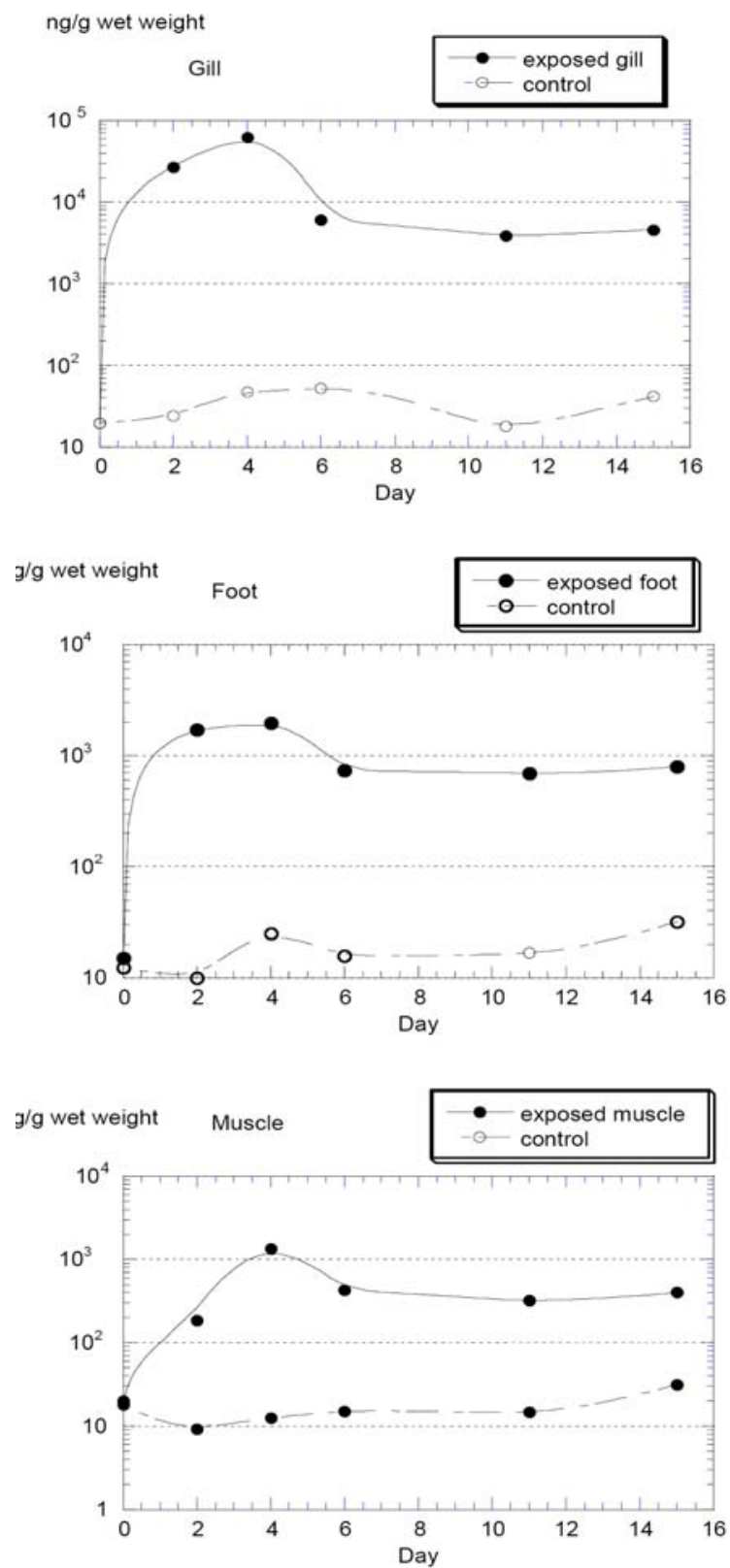

Fig 1: Patterns of accumulation and depuration of total mercury in gill, mantle, foot, gonad, muscle and byssus of $P$. viridis based on a semi-log scale (log scale on $\mathrm{Y}$ axis).

Since the gill had the highest BCF value after 4 days of $\mathrm{Hg}$ exposure, the elevated $\mathrm{Hg}$ levels in the gill probably reflected the levels of environmental $\mathrm{Hg}$ in the seawater while the $\mathrm{Hg}$ concentrations in the muscle, mantle, foot and gonad were more accurately representative of the actual incorporation and accumulation of the metal following the uptake of $\mathrm{Hg}$ being present at much lower concentrations in these tissues than in the gill and byssus. Yan et al. (1997) found elevations of tissue glutathione in $P$. viridis after an inorganic $\mathrm{Hg}$ exposure which was related to $\mathrm{Hg}$ binding.
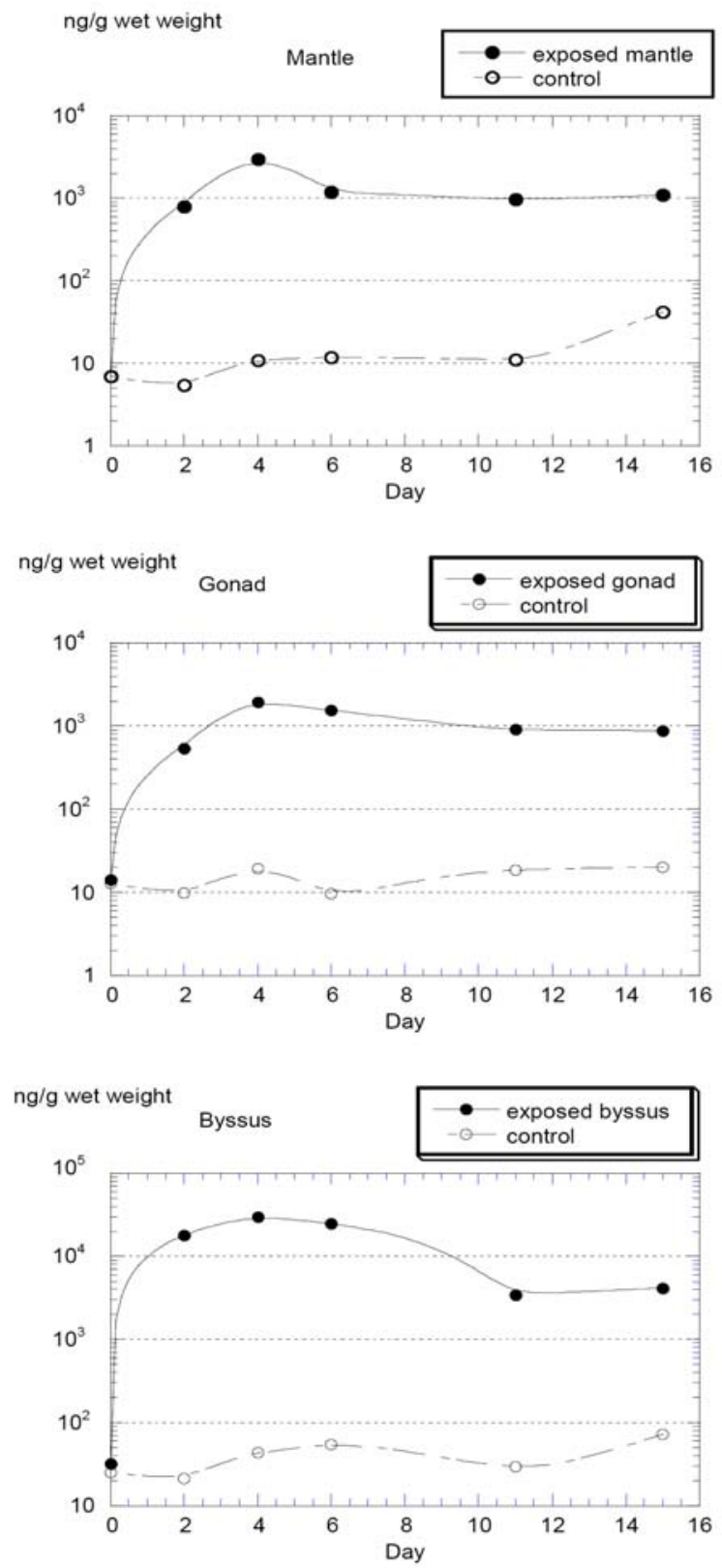

from the seawater. The higher $\mathrm{BCF}$ values and $\mathrm{Hg}$ levels in the gill and byssus after 4 days of exposure when compared to the other soft tissues examined indicated that the gill and byssus possessed a markedly different mechanism for $\mathrm{Hg}$ accumulation or storage from the other soft tissues. Eganhouse and Young (1978) reported that muscles of Mytilus 
californianus, exposed to waters near a submarine wastewater discharge, exhibited a low rate of $\mathrm{Hg}$ accumulation. Since the gill plays a role in filterfeeding activities and is the first organ in contact with environmental seawater, $\mathrm{Hg}$ was accumulated in the gill at a high concentration. This reflected the dominance of the gill as a site of $\mathrm{Hg}$ uptake (George, 1982; King and Davies, 1987). The gill was also reported to have the largest total surface per volume and therefore allowed much contact and interaction with $\mathrm{Hg}$ from seawater (Tessier and Campbell, 1987). Other studies also reported that the highest Hg levels were in the gill when compared to the other tissues of mussels. King and Davies (1987) reported that the gill of M. edulis accumulated $1600 \mathrm{ng} / \mathrm{g}$ after 3 days exposure to $1 \mu \mathrm{g} / \mathrm{L} \mathrm{Hg}$. In our study, gill of $P$. viridis recorded $62,500 \mathrm{ng} / \mathrm{g}$ after 4 days exposure to 100 $\mu \mathrm{g} / \mathrm{L} \mathrm{Hg}$. Besides Hg, Patel and Anthony (1991) reported that during the first few days of $\mathrm{Cd}$ exposure, the highest $\mathrm{Cd}$ level was recorded in the gill of Anadara granosa, followed by the cockle's digestive glands, mantle, visceral mass, adductor muscle and foot. A high $\mathrm{Cd}$ concentration was reported in the gill of M. edulis which was facilitated by the presence of ion-binding proteins and mucus (Cunningham, 1978; Marshall and Talbot, 1979).

Table 1: Bioconcentration factor (BCF) values after 4 days of $\mathrm{Hg}$ exposure and linear regression analysis of $\mathrm{Hg}$ concentrations (ng/g) in individual organs of $P$. viridis during the depuration period.

\begin{tabular}{ccccc}
\hline Organs & $\begin{array}{c}\text { BFC } \\
\text { values }\end{array}$ & Power relationships & $\begin{array}{c}\mathrm{b} \text { (depuration rate } \\
\text { coefficients) }\end{array}$ & $R$-values \\
Byssus & $300.6 \mathbf{a}$ & $\mathrm{Y}=5.980 \mathrm{X}^{-0.196}$ & -0.196 & 0.938 \\
Gill & $624.5 \mathbf{a}$ & $\mathrm{Y}=5.812 \mathrm{X}^{-0.189}$ & -0.189 & 0.845 \\
Mantle & $29.9 \mathbf{c}$ & $\mathrm{Y}=3.822 \mathrm{X}^{-0.095}$ & -0.095 & 0.825 \\
Gonad & $19.4 \mathbf{d e}$ & $\mathrm{Y}=3.737 \mathrm{X}^{-0.092}$ & -0.092 & 0.985 \\
Foot & $19.6 \mathbf{d e}$ & $\mathrm{Y}=3.547 \mathrm{X}^{-0.086}$ & -0.086 & 0.739 \\
Muscle & $13.4 \mathbf{e}$ & $\mathrm{Y}=3.571 \mathrm{X}^{-0.134}$ & -0.134 & 0.815 \\
\hline
\end{tabular}

Note: Student-Newman-Keuls (SNK) comparisons of metal levels in different soft tissues of $P$. viridis. Means with different letters are significantly different, $P<0.05$.

The matter of the byssus of $P$. viridis being a route of $\mathrm{Hg}$ excretion is interesting. Pentreath (1973) and Goldberg et al. (1978) suggested that the mussel byssus could have been used for metal excretion when the metal concentration in the byssus was high. According to Coomb and Keller (1982), the formation of byssal threads in M. edulis required the expenditure of a substantial amount of energy and materials and the byssus was excreted from the byssal glands in the foot. According to Ikuta (1986), the mussel byssus was composed of hard tanned protein. This material might contribute to the elevated level of $\mathrm{Hg}$ found in the byssus of $P$. viridis since it could have more binding sites for Hg. Szefer et al. (1999) reported that the byssus of M. edulis could become a good biomonitoring material for the identification of coastal areas exposed to $\mathrm{Hg}$ contamination. Since the byssus and gill of $P$. viridis both had high $\mathrm{BCF}$ values and high depuration rate coefficients, they are sensitive to $\mathrm{Hg}$ contamination.
Table 2: Mercury levels in fecal accumulation and depuration

\begin{tabular}{cccc}
\hline Day & $\begin{array}{c}\text { Control } \\
(\mathrm{ng} / \mathrm{g})\end{array}$ & $\begin{array}{c}\text { Hg exposed } \\
(\mathrm{ng} / \mathrm{g})\end{array}$ & $\begin{array}{c}\text { materials of } P \text {. viridis during the } \\
\text { periods. }\end{array}$ \\
0 & 47.6 & 52.6 & \\
$\begin{array}{c}\text { Accumulation } \\
2\end{array}$ & 373.0 & $>100,000$ \\
4 & 328.0 & $>100,000$ \\
Depuration & & & \\
6 & 242.0 & $>100,000$ \\
11 & 121.0 & $>100,000$ \\
15 & 365.0 & $>100,000$ \\
\hline
\end{tabular}

The observation of high levels of $\mathrm{Hg}$ in the fecal materials at all sampling days was expected. The result indicated that the $\mathrm{Hg}$ accumulated in the soft tissues of $P$. viridis was excreted through the feces which also contained uningested filtered algae or particles that contained high levels of $\mathrm{Hg}$. This 
phenomenon was an indication that the contaminated particles in the seawater could be retained and eliminated as fecal materials. We assume that the same phenomenon would occur under the natural field conditions although it has yet to be proven. This may help us to understand the role of the filter feeding mussels in the coastal waters. According to Kuenzler (1961), the filter-feeding mussel acted as a nutrient retention mechanism in the coastal environment. Based on his suggestion, P. viridis could play a role in the $\mathrm{Hg}$ retention mechanism of coastal waters. Since inorganic $\mathrm{Hg}$ could be biologically converted into methyl-Hg by factors such as microbial activity and the concentration of bioavailable $\mathrm{Hg}$ in the marine environment (D'itri, 1991; Ullrich et al., 2001), these fecal materials together with the organic nutrients would become the source of $\mathrm{Hg}$ contamination for the primary producers in the coastal waters. The experimental treatment with inorganic $\mathrm{Hg}$ in dissolved solution does not, however, provide a satisfactory analogy for the field samples. This is due to the 'very' high levels of $\mathrm{Hg}$ exposure used in this laboratory study in addition to other physico-chemical influences in the field.

Conclusion: This laboratory experiment indicated the significant importance of inorganic $\mathrm{Hg}$ from the dissolved phase as a source of $\mathrm{Hg}$ accumulation in $P$. viridis. The accumulation and depuration capabilities of $P$. viridis indicated that the mussel was capable of adjusting to the changing availability of ambient inorganic $\mathrm{Hg}$. The accumulation of inorganic $\mathrm{Hg}$ in the byssus and in the different soft tissues of $P$. viridis is different from one another. Despite having exposed to a 'very' high level of inorganic Hg level, all the mussels survived throughout the experimental period indicated that the high inorganic $\mathrm{Hg}$ was not toxic to $P$. viridis since the mussel has a high tolerance to inorganic $\mathrm{Hg}$ exposure. The high accumulation of $\mathrm{Hg}$ and hardly any elimination of $\mathrm{Hg}$ from the soft tissues after 11 days of depuration indicated that most of the accumulated $\mathrm{Hg}$ was tightly bound to metallothionein and it was not easily mobilized. The byssus is a potential excretion route of $\mathrm{Hg}$ while very high levels of $\mathrm{Hg}$ found in the fecal materials indicated that $P$. viridis could act as a $\mathrm{Hg}$ retention mechanism.

\section{REFERENCES}

Alonso, D; Pineda, P; Olivero, J; Gonzalez, H; Campos, N (2000). Mercury levels in muscle of two fish species and sediments from the Cartagena Bay and the Cienaga Grande de Santa Marta, Colombia. Environ Pollut 109: 157-163.
Broman, D; Lindqvist, L; Lundbergh, I (1991). Cadmium and zinc in Mytilus edulis (L.) from the Bothnian and the Northern Baltic Proper. Environ Pollut 74: 227-244.

Bryan, G W (1984). Pollution due to heavy metals and their compounds. Mar Ecol 5: 1289-1431.

Cherian, M G; Goyer R A (1978). Metallothioneins and their role in the metabolism and toxicity of metals. Life Sci 23: 1-10.

Coombs, T L; Keller, P J (1982). Mytilus byssal thread as an environmental marker for metals. Aquat Toxicol 1:291-300.

Cunningham, P A (1978). The use of bivalve molluscs in heavy metal pollution, In Marine pollution functional responses, W.B. Vernberg, F.A. Thurberg, A. Calabrese and F.J. Vernberg, eds., London: Academic Press, pp. 183-221.

D'itri, F M (1991). Mercury contamination- What we have learned since Minamata. Environ Monitor Asses 19: 165-182.

Davies, I M; Pirie, J M (1978). The mussel Mytilus edulis as a bio-assay organism for mercury in seawater. Mar Pollut Bull 9: 128-132.

Day, R W; Quinn G P (1989). Comparisons of treatments after an analysis of variance in ecology. Ecol Monograph 59: 433-463.

De Gregori, I; Delgado, D; Pinochet, H; Gras, N; Munoz, L; Bruhn, C; Navarrete, G (1984). Cadmium, lead, copper and mercury levels in fresh and canned bivalve mussels Tagelus dombeii (Navajuela) and Semelle solida (Almeja) from the Chilean Coast. Sci Total Environ 148: 1-10.

Eganhouse, R B.; Young, D R (1978). In Situ uptake of mercury by the intertidal mussel, Mytilus californianus. Mar Pollut Bull 9: 214-217.

George, S G (1982). Subcellular accumulation and detoxification of metals in aquatic animals. In Physiological mechanisms of marine pollutants toxicity, W.B. Vernberg, A. Calabrese, F.P. Thurberg and F.J. Vernberg, eds., New York: Academic Press, pp. 3-52.

Goldberg, E D (1975). The Mussel Watch - A first step in global marine monitoring. Mar Pollut Bull 6: 111. 
Goldberg, E D; Bowen, V T; Farrington, J W; Harvey, G; Martin, J H; Parker, P L; Risebrough, R W; Robertson, W; Schneider, W; Gamble, E (1978). The Mussel Watch. Environ Conser 5: 101-125.

Ikuta, K (1986). Metal concentrations in byssuses and soft bodies of bivalves. Bull Agric Miyazaki Uni 33: $255-264$.

Ismail, A; Yap, C K; Zakaria, M P; Tanabe, S; Takada, H; Ismail, A R (2000). Green-lipped mussel Perna viridis (L.) as a biomonitoring agent for heavy metals in the west coast Of Peninsular Malaysia. In Towards Sustainable Management of the Straits of Malacca, Technical and Financial Options. M. Shariff, F.M. Yusoff, N. Gopinath, H.M. Ibrahim and A. Nik Mustapha, eds., Malacca Straits Research and Development Centre, University Putra Malaysia, Serdang, Malaysia, pp. 553-559.

King, D G; Davies, I M (1987). Laboratory and field studies of the accumulation of inorganic mercury by the mussel Mytilus edulis (L.). Mar Pollut Bull 18: 40-45.

Kuenzler, E J (1961). Phosphorus budget of a mussel population. Limnol Oceanogr 6: 400-415.

Kurland, L (1960). The outbreak of neorologic disorder in Minamata, Japan and its relationship to the ingestion of seafood contaminated by mercuric compounds. World Neurology 1: 239261.

Leah, R T; Evans, S J; Johnson, M S (1982). Mercury in flounder (Platichthys flesus L.) from estuaries and coastal waters of the north-east Irish Sea. Environ Pollut 75: 317-322.

Mance, G I (1987). Pollution threat of heavy metals in aquatic environments. London: Elsevier Science, $372 \mathrm{pp}$.

Marshall, A T; Talbot, V (1979). Accumulation of cadmium and lead in the gill of Mytilus edulis: $\mathrm{x}$ ray microanalysis and chemical analysis. Chem Biol Interactions 27: 111-123.

May, K; Stoeppler, M; Reisinger, K J (1987). Studies in the ratio total mercury/methylmercury in the aquatic food chain. Toxicol Environ Chem 13: 153-159.

Moraes, L A P; Lenzi E; Luchese E B (1997). Mercury in two fish species from the Parana
River floodplain, Parana, Brazil. Environ Pollut 98: 123-127.

Patel, B; Anthony, K (1991). Uptake of cadmium in tropical marine Lamellibranchs and effects on physiological behaviour, Mar. Biol. 108: . 457470.

Pentreath, R J (1973). The accumulation from water of ${ }^{65} \mathrm{Zn},{ }^{54} \mathrm{Mn},{ }^{58} \mathrm{Co}$ and ${ }^{59} \mathrm{Fe}$ by the mussel Mytilus edulis. J Mar Biol Assoc UK 53: 127143.

Phillips, D J H (1980). Quantitative aquatic biological indicators: their use to monitor trace metal and organochlorine pollution, London: Applied Science, 488 pp.

Phillips, D J H (1985). Organochlorines and trace metals in green-lipped mussels Perna viridis from Hong Kong waters: a test of indicator ability. Mar Ecol Prog Ser 21: 251-258.

Phillips, D J H (1991). Selected trace elements and the use of biomonitors in subtropical and tropical marine ecosystems. Rev Environ Contam Toxicol 120: 105-129.

Phillips, D J H; Rainbow, P S (1993). Biomonitoring of trace aquatic contaminants, London: Elsevier Science, 371pp.

Phillips, D J H; Segar, D A (1986). Use of bioindicator organism to monitoring contaminants: programme design imperatives. Mar Pollut Bull 17: 10-17.

Reinfelder, J R; Fisher, N S; Luoma, S N; Nichols, J W; Wang, W -X (1998). Trace element trophic transfer in aquatic organisms: a critique of the kinetic model approach. Sci Total Environ 219: 117-135.

Roesijadi, G (1980). The significance of low molecular weight, metallothionein-like proteins in marine invertebrates: current status. Mar Environ Res 4: 167-179.

Sakamoto, H; Taiyasu, T; Ichikawa, T (1999). Mercury contents in marine environmental samples of Malaysia and Japan. In Proceedings of the Tenth JSPS/VCC Joint Seminar on Marine and Fishery Sciences "Sustainable Utilization of Marine Resources", Saadon, M.N., Abdullah, S.A., Sheriff, S.N., Ariffin, N.A., eds., College Universiti Terengganu, Malaysia, pp. 229-241. 
Schuhmacher, M; Batiste, J; Bosqeu, M A; Domingo, J L; Corbella, J (1994). Mercury concentrations in marine species from the coastal area of Tarragona Province, Spain. Dietary intake of mercury through fish and seafood consumption. Sci Total Environ 156: 269-273.

Szefer, P; Ikuta, K; Frelek, K; Zdrojewska, I; Nabrzyski, M (1999). Mercury and other trace metals (Ag, Cr, Co and $\mathrm{Ni}$ ) in soft tissue and byssus of Mytilus edulis from the east coast of Kyushu Island, Japan. Sci Total Environ 229: 227-234.

Tanabe, S (2000). Asia-Pacific Mussel Watch progress report. Mar Pollut Bull 40: 651.

Tessier, A; Campbell, P G C (1987). Partitioning of trace metals in sediments: relationship with bioavailability. Hydrobiologia 149: 43-52.
Ullrich, S M; Tanton, T W; Abdrashitova, S A (2001). Mercury in the aquatic environment: A review of factors affecting methylation. Critical Rev Environ Sci Tech 31: 241-293.

Wong, C K; Cheung, R Y H; Wong, M H (2000). Heavy metal concentrations in green-lipped mussels collected from Tolo Harbour and markets in Hong Kong and Shenzhen. Environ Pollut 109: 165-171.

Yan, T; Tee, L H; Sin, Y M (1997). Effects of mercury and lead on tissue glutathione of the green mussel, Perna viridis L. Bull Environ Contam Toxicol 58: 845-850.

Zhou, H Y; Wong, M H (2000). Mercury accumulation in freshwater fish emphasis on the dietary influence. Wat Res 34: 4234-4242. 